\title{
Prosthetic rehabilitation of the sequelae of labio-maxillo-palatal clefts:

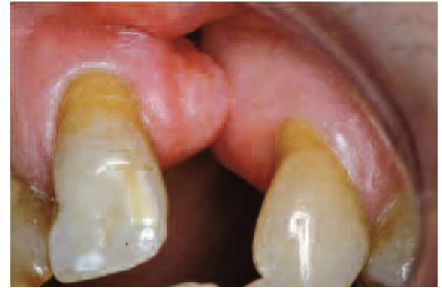 end of the growth period and evolution
}

\author{
Aude BICHET, Christian MOLÉ, Olivier WEISSENBACH, \\ Étienne SIMON
}

\begin{abstract} surgical and prosthetic procedures.

KEY WORDS

Labio-maxillo-palatal cleft

Interdisciplinary medical team

Prosthetic rehabilitation

Implants and clefts

Periodontal reconstructive surgery

Sequelae
\end{abstract}

With an average frequency of 1/800 births in France, labio-maxillo-palatal clefts (LMPC) are among the most frequent congenital malformations. They raise functional, esthetic, psychological and socio-familial problems that must be managed with an interdisciplinary approach. Within the medical team, the dentist must, by way of prosthetic restorations, compensate for certain sequelae and deficiencies. According to the severity of the case and the success of the treatments, the typical restoration can be limited to replacing the missing lateral incisor, or the restoration may require undertaking comprehensive treatments involving a much more specialized arsenal of

Address for correspondence:

\section{MOLÉ}

Stomatologie et Chirurgie plastique de la face, CHU Nancy,

29 avenue du Maréchal de Lattre de Tassigny,

54035 Nancy cedex

drchristianmole@free.fr

Article available at http://www.jdao-journal.org or http.
Declared conflicts of interest: None Article received: 03-2012 Accepted for publication: 05-2012 


\section{1 - INTRODUCTION}

LMPC are anomalies of embryonic orofacial development which can arise in the absence of partial or complete fusion of certain facial buds. These anomalies which frequently present with LMPC cause functional and esthetic problems requiring medical care from the moment of birth.

The main task of an interdisciplinary team dealing with clefts is to reach a common goal. They achieve this objective by assessing different medical strategies and by then choosing the best treatment for their patients.

Prosthetic rehabilitation is the ultimate goal of comprehensive case management and the role of the dentist in this process is of utmost importance. Given what we now know about periodontal and prosthetic procedures, today it is possible to choose the preferred therapeutic approaches for the management of LMPC sequelae.

In order to select the best treatment plan, the dentist must take into consideration all the anatomical defects encountered during the oral examination of an adult patient with a LMPC who is at the end of the growth period and who has either ended or interrupted surgical and orthodontic treatments.

\section{2 - SURGICAL PROCEDURES}

Prosthetic rehabilitation for a patient who is being treated for a cleft, requires planning for very diverse medical conditions. It may be simply a "single lateral" that is missing or as serious as a significant loss of dental structure and crestal bone from the atrophied maxilla. The difference for these patients is the considerable attention that is paid to the special characteristics of LMPC.

\section{2 - 1 - Problems of facial context}

The degree of difficulty in obtaining an optimal result with prostheses depends on an individual and comprehensive study of different clinical elements such as facial symmetry, disharmony of the midface in all three planes of space leading to midline asymmetry ${ }^{20}$. The facial context for a patient with a LMPC varies according to the maxillary growth as well as the labial and nasal sequelae.

Maxillary hypoplasia is a frequent sequela in cleft palate patients. It is three-dimensional and presents a concave profile, a flattening of the midface, and a downward curving of the upper $\operatorname{lip}^{27}$.

Structural deformities of the lip are hard to distinguish from nasal sequelae. We see thin, long and short lips, as well as defects of the vermillon border, cupid's bow, and philtrum ${ }^{39}$.

The nasal sequelae vary according to the type of cleft. With unilateral clefts, asymmetry of the face is noticeable ${ }^{38}$ and generally we see a shortened columella in cases of bilateral clefts ${ }^{24}$. 
These numerous nasal and labial sequelae play an important role in the esthetic success of prosthetic treatment.

\section{2 - 2 - The muco-gingival problem}

The deformities of the labial mucosa are frequently manifested by a narrow mouth opening, scarred flanges and frenums as well as palatal and/or residual buccal fistulas (Figs. 1 and 2) 29,28,37,38. The frenums can exert traction that is apical in relation to the soft tissues and thereby can participate in the development of recessions. In addition, they work against one another during full denture prosthetic rehabilitation, when attempts are made to obtain a working marginal peripheral junction.

All the abnormalities associated with LMPC, ageneses, supernumerary buds and teeth, delayed eruption, are accompanied by a quantitative decrease in surrounding tissues ${ }^{3,34}$. A decrease in attached gingiva and alveolar mucosa is evident. These patients are at risk for periodontal diseases and recessions (Fig. 2) ${ }^{28}$.

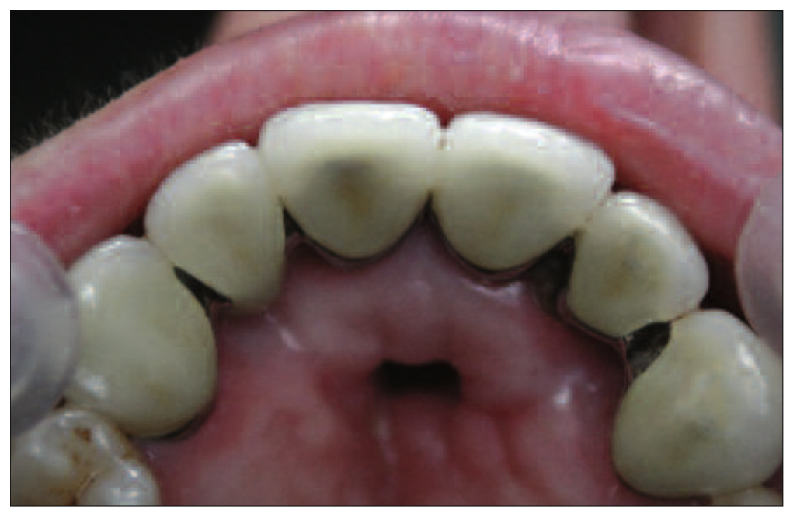

Figure 1

An example of a persistent palatal fistula.
As for an alveolar cleft, we frequently observe epithelialization whether the space is closed or opened by orthodontic procedures (Figs. 3 and 4).

The cleft can be examined by a dental explorer or periodontal probe, without local anesthesia.

The three-dimensional morphology of the missing periodontal structure can present a more or less pinched facial shape, that is either simple, vertical and straight, or more or less complex and laterally oriented ${ }^{22}$.

Mercier has proposed a way to resolve this particular problem by making gingivoplasties ${ }^{21}$, a solution that we find inadequate today, because of the indisputable support created by the insertion of conjunctive tissue grafts $^{23}$.

\section{2 - 3 - The bone problem}

A prosthetic resolution for treatment is often disrupted or even stopped very frequently by a sequela - the persistence of an alveolar fissure of varying depth (Fig. 5) ${ }^{23}$.

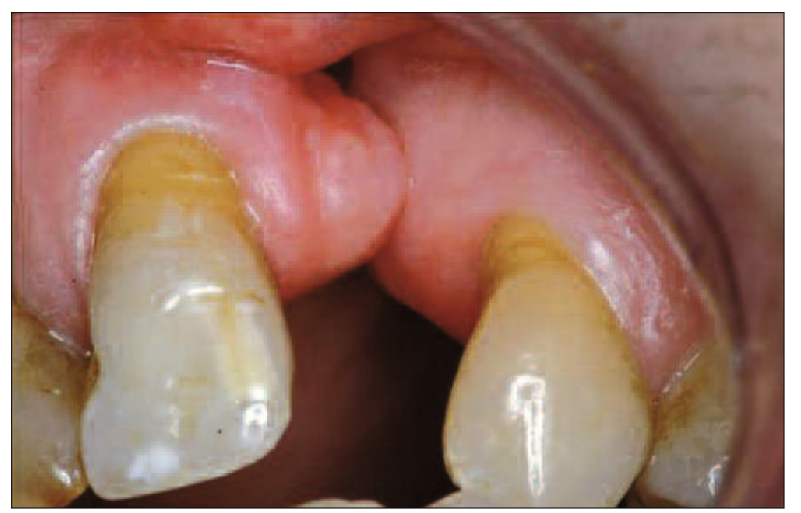

Figure 2

Fistula and persistent buccal-palatal opening. 


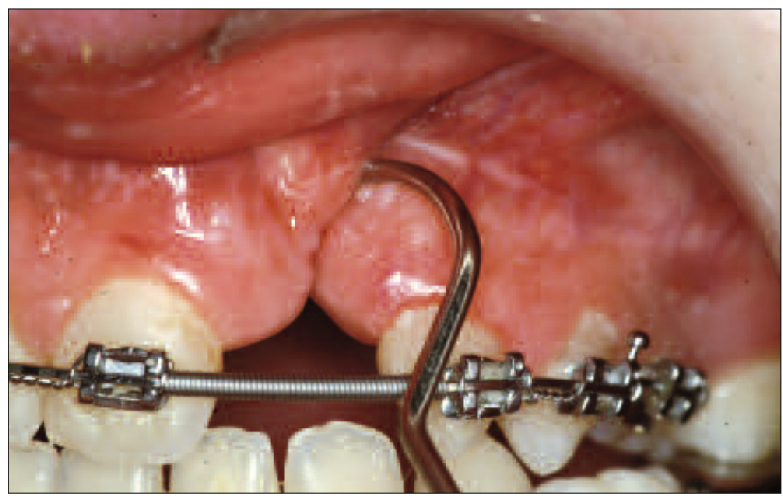

Figure 3

Residual epithelial fold on the alveolar cleft.

The residual alveolus adjoining clefts shows decreased volume both in bucco-lingual and apical-coronal dimensions, at the Class III level in the Seibert classification. This deficiency is sometimes imperceptible but can be verified with a silk thread or an explorer ${ }^{15,33}$.

Practitioners usually follow the status of cleft palate patients with panoramic $X$-rays throughout the growth period.

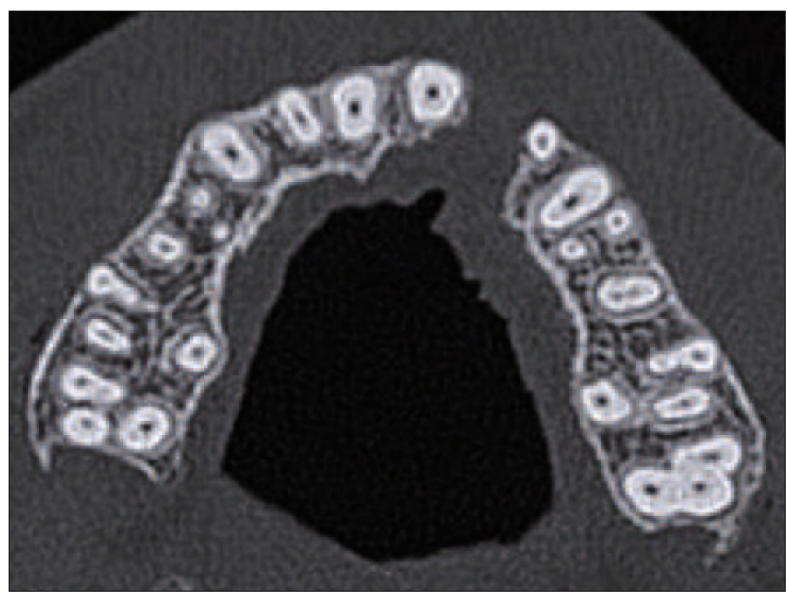

Figure 5

The alveolar fissure often penetrates widely as deep as the roots of teeth where it reduces their periodontal cover.

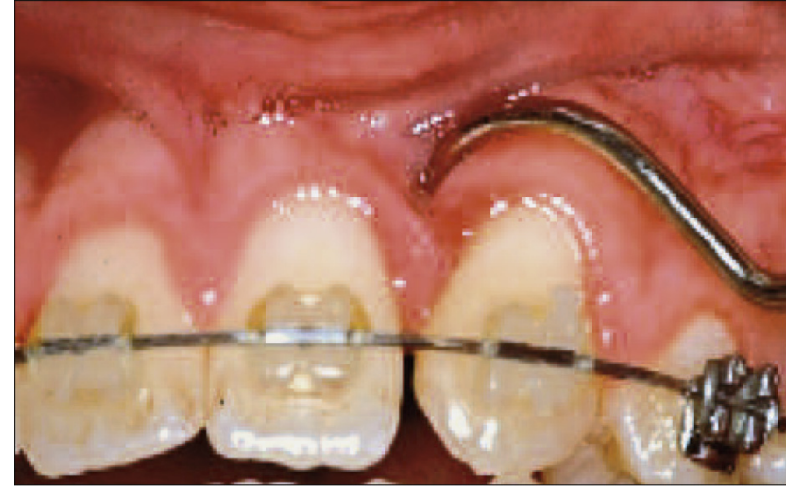

Figure 4

Idem on the orthodontically closed space.

But this conventional radiological assessment cannot provide a good tridimensional appreciation of the defect. But with 3D images, a multi-axial recombination of the acquired images reconstructed in two dimensions, practitioners can very rapidly determine that, in the majority of cases, the loss of residual osseous substance is profound, multi-dimensional, invaginated, and complex in form (Fig. 6) ${ }^{22}$.

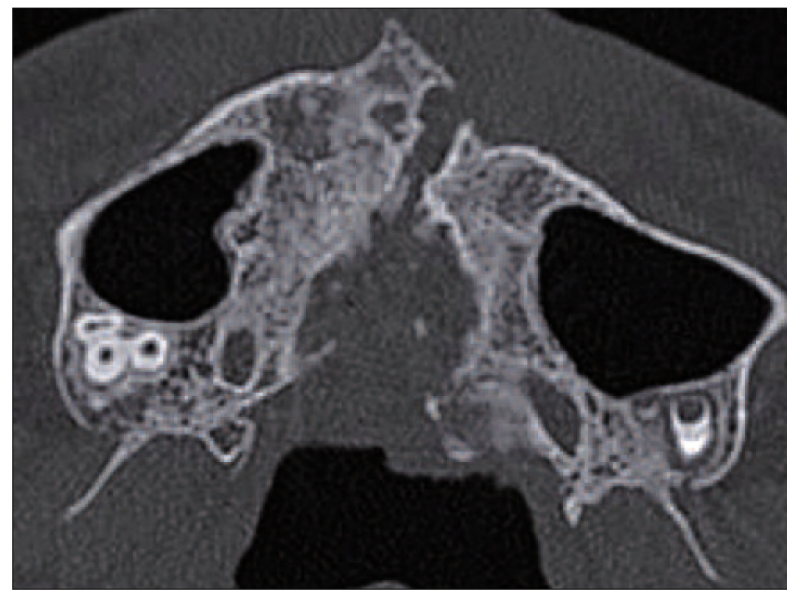

Figure 6

At a high level the cleft narrows but becomes highly invaginated and more complex in its form. 
The indications and contra-indications for new grafts do make up the entire basis for management of residual osseous deficits of labio-maxillary-palatal clefts at the end of the growth period. The indications and contra-indications for grafts designed to assist placement of implants and the integration of teeth bordering the cleft also play a role in formation of a prosthetic plan.

Certain very grave osseous sequelae can lead to virtually complete destruction of the maxilla. This development can occur in patients who endured multiple operations or who have disappeared from the surveillance of the treatment team. Sometimes the persistent bone loss at this growth stage is so great that bone grafts are not only needed as preparation for proposed implants but also for reconstruction of a bone crest adapted for future prosthetic rehabilitation $^{30}$.

\section{2 - 4 - Dental problems}

The decision concerning the nature of the final surgico-prosthetic reconstruction depends not only on the volume of residual bone around the cleft itself but also on the status of the teeth surrounding it.

These teeth, which have probably lost much of their periodontal support from gingival recession, may be hypersensitive to thermal changes or to contact because their reduced periodontal coverage can no longer protect them against physiological constraints as they become increasingly mobile. This makes placement of retention devices essential (see clinical case $n^{0} 1$ ).
Many teeth on the borders of clefts show malformations of shape and structure (Fig. 7). Forty percent of permanent laterals bordering clefts are congenitally absent and doubling of teeth, dysplasia, hypoplasia and dilacerations ${ }^{2}$ are frequent (Fig. 8).

Their prognosis depends upon:

- the quantity of remaining attached gingiva,

- the quantity of alveolar bone,

- the crown root relationship,

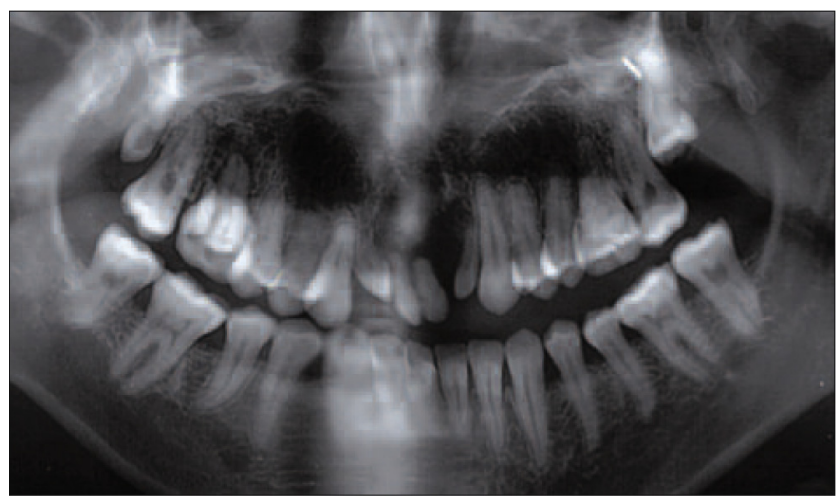

Figure 7

This panoramic film depicts the congenital absence or malformations of certain teeth.

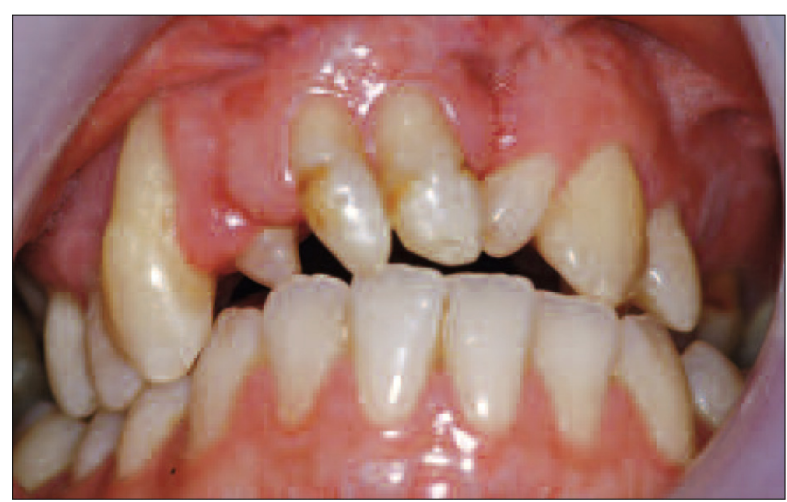

Figure 8

Intraoral view of same patient shows serious periodontal loss of teeth bordering the cleft. 
- the type of malformation,

- the quality of osseous and soft tissue support,

- the presence, or absence, of gingival inflammation,

- the control of plaque,

- and the type of prosthesis to be employed $^{4}$.

The practitioner must pay scrupulous attention to the maintenance and integration of teeth bordering the cleft as the prosthetic restoration is conceived, placed, and put into use.

\section{2 - 5 - Occlusal problems}

Cleft palate patients that surgeons see will have previously benefited by dentofacial orthopedic and/or orthodontic intervention that, after a long and arduous treatment, has provided them with good functional occlusion supported by skeletal solidity whose stability practitioners must assure with excellent retention procedures ${ }^{14}$ appropriately conceived to last and to suit the available space and the prostheses they serve ${ }^{22}$.

Occasionally we have to serve patients who habitually miss office visits and whose occlusion is unstable. With them we encounter dento-skeletal sequelae that affect the maxilla in the three dimensions of space: maxillary retrusions, endo-maxillae with or without endo-alveoli, and insufficient vertical maxillary development ${ }^{2,6,10}$. In performing the prosthetic restoration for them, practitioners must strive to create for them an occlusion that is the most harmonious and close to ideal as possible.

But they will have to contend with the faulty arrangement of dental buds that the cleft has provoked in the incisors, canines, and premolars along its side.

\section{2 - 6 - Oral hygiene problems}

Factors provoking and maintaining gingival inflammation in patients with clefts are aggravated because gingival edges are interrupted and irregular, teeth are malpositioned, and the necessary orthodontic and retention devices they have to wear all encourage plaque formation. The resultant constant inflammation can provoke gingival destruction with evolving migration of attachment (Fig. 9) ${ }^{22}$.

To improve oral hygiene, practitioners must not only instruct patients in brushing and use of floss but also must remove any adhesions and supplementary freni and augment the quantity of attached gingiva, those deepening the cheek cavity and, finally, construct prosthesis that

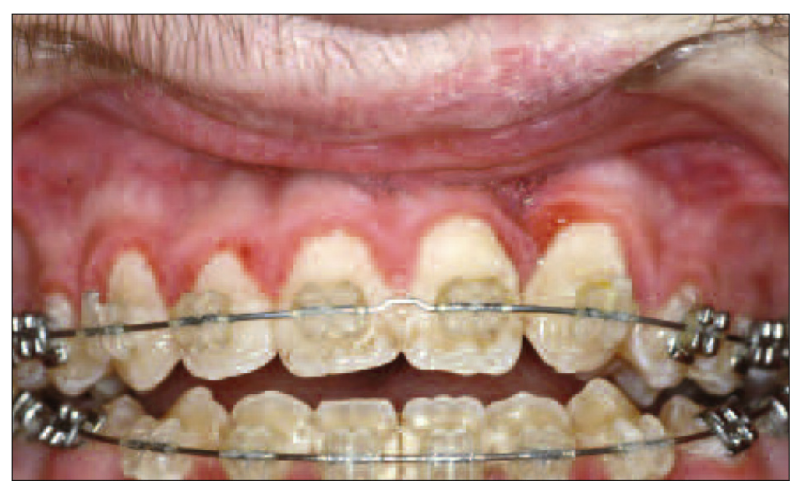

Figure 9

Bacterial plaque is often found in aggravated quantities in sectors where cleft sequelae are present. Tormented gingiva, invaginated alveolar mucosa, which is sensitive to brushing, and scar tissue adhesions are the responsible factor provoking these accumulations. 


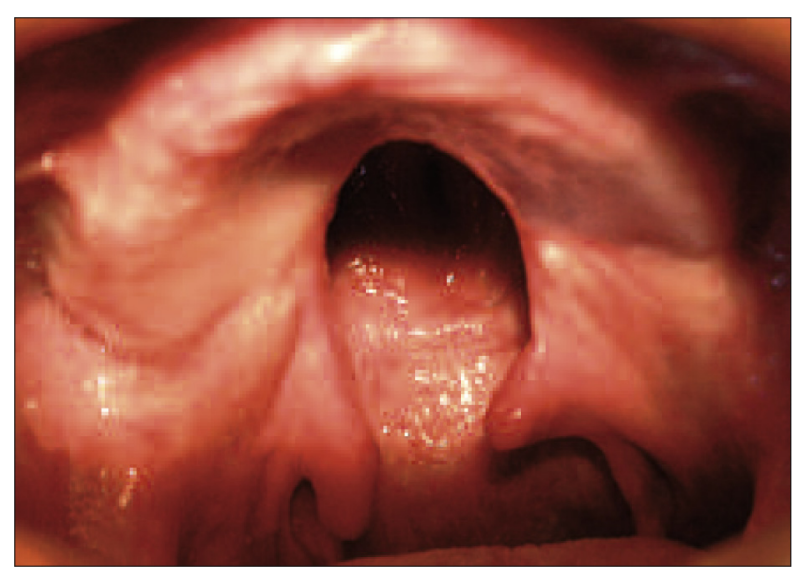

Figure 10

Large soft palate cleft.

reflects the best principles of good oral health.

\section{2 - 7 - Soft palate problems}

After the soft palate has been repaired practitioners may be confronted by some residual anatomic problems such as a still divided velum, velum that is too short, inert, or even absent (Fig. 10) ${ }^{12}$.

But practitioners can seal any remaining defects with a properly designed velo-palatal prosthesis whose hermetic seal allows patients to process foods and liquids correctly.

In contrast to subjects whose loss of maxillary substance is iatrogenic, cleft patients suffer disturbances of phonation. This functional sequela is explained by the congenital nature of the anomaly. It is highly desirable for these patients to have speech therapy to restore muscle tone and to teach them how to make sounds correctly.

\section{2 - 8 - Inter-personal relations problems}

In many countries the state does not pay for all labio-maxillary-palatal cleft treatment so practitioners must take the financial status of their patients' families into consideration ${ }^{18}$ especially when making decisions about the prosthesis. They must consider the socio-economic integration of each patient in order to determine the therapeutic solution best suited to individual needs.

\section{2 - 9 - Problems of prognosis and maintenance}

The prognosis for prosthetic treatment of cleft patients depends on:

- the results of the initial treatment,

- the secondary treatment of the alveolar sequelae,

- the practitioner's learning curve and his knowledge,

- the learning curve of patients and the ability to control plaque.

Numerous case histories have been reported in the literature but very few retrospective or prospective studies on different types of prostheses have been published ${ }^{4}$. 


\section{3 - SPECIFIC FEATURES OF CONVENTIONAL PROSTHESES FOR CLEFT PATIENTS}

\section{3 - 1 - Bonded bridges}

\section{- Indications}

A bonded bridge is a temporary solution used to maintain space created by orthodontic treatment ${ }^{29,30}$. It is esthetically satisfactory but not especially strong in resisting the stress of the normal functional activity of the masticatory apparatus. It can be used in a young patient to replace a congenitally absent lateral incisor or premolar tooth. In this type of reconstruction, an osseous or epithelioconjuctive bridge should stabilize the alveolar fragments ${ }^{22}$.

\section{- Criteria for decision-making} (Table 1).

\section{3 - 2 - Bridge providing a substitute for missing tooth}

\section{- Indications}

This prosthetic solution to the problem of teeth missing from the arch also serves as a working retainer for teeth on the border of the cleft that are often fragile and to prevent relapse, a frequently reported condition related to the presence of fibrous scar tissue.

According to the report of Roisin et al., in 1988 the presence of continuity between the borders of the cleft is indispensable because it allows practitioners to abide by the

\begin{tabular}{|c|c|}
\hline Favorable parameters & Unfavorable parameters \\
\hline Patients younger than 18 & Dental dysplasia \\
\hline Good plaque control & Broken down teeth \\
\hline Healthy dentition & Many mobile teeth \\
\hline Sufficient crown height & Many missing teeth \\
\hline Agenesis of laterals or premolars & Poor plaque control \\
\hline Healthy periodontium of teeth bordering cleft & Serious anterior overbite \\
\hline Mobility of teeth bordering cleft more than 1 & Many malpositioned teeth \\
\hline $\begin{array}{l}\text { Osseous or epithelio-conjunctve bridge } \\
\text { between borders of cleft (tibial, } \\
\text { gingivoperiostoplasty, deep conjunctive graft) }\end{array}$ & $\begin{array}{l}\text { Bucco-nasal communication alveolar breach } \\
\text { and/or residual palatal division }\end{array}$ \\
\hline $\begin{array}{l}\text { Bone quantity and quality insufficient for im- } \\
\text { plant }\end{array}$ & Unstable occlusion \\
\hline
\end{tabular}

Table 1 
established rules for prostheses made for unimpaired patients. Today, with surgery, the maxillary fragments may be joined together ${ }^{6,32}$.

Bridges constructed on teeth constitute the treatment of reference when the peripheral dentition is broken down or dysplastic ${ }^{30,31}$.

Recessions, lack of attached and keratinized gingiva as well as the morphological deficit presented by the edentulous crest must be corrected by specific periodontal treatment ${ }^{7,20}$.

Some authors $9,25,35$ prefer replacing a missing upper lateral incisor with a bridge, not an implant, which is difficult and risky to place in cleft situations.

- Clinical case $\mathbf{n}^{\circ} \mathbf{1}$ (Figs. 11 to 15 )

- Criteria for decision making (Table II)

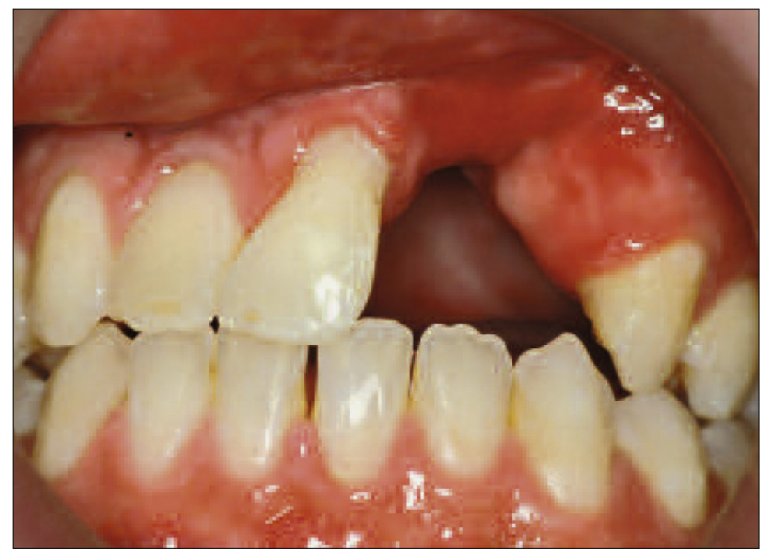

Figure 11

This 21 year-old male consulted us after orthodontic treatment because of substantial loss of crestal bone at the site of a left unilateral cleft. Note the weakness of the periodontal support for the upper right central incisor.

\section{3- 3 - Implant borne prostheses}

\section{- Indications}

Screwed-on implants are now most frequently used for replacing missing or dystrophic upper lateral incisors. But using implant-borne crowns to rehabilitate the sequelae of the cleft confronts practitioners with a truly challenging task. An array of difficulties accumulates to beleaguer practitioners attempting to employ this difficult and sometimes impossible type of rehabilitation. Only the presence of alveolar bone of sufficient quality and quantity can guarantee that practitioners will be able to initially position an implant correctly and then place a single unit adapted restoration properly upon it $^{22}$.

For patients with no contra-indications, an implant supported prosthetic replacement is the ideal technique in agenesis cases. The difficulty prac-

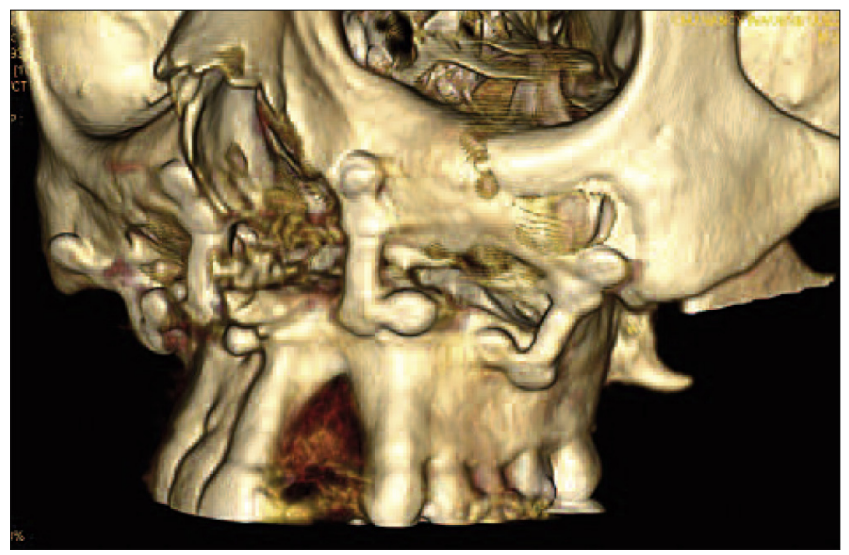

Figure 12

This 3D image objectifies the bi-cortical osseous deficit and the location of the alveolar bridge created by all the preliminary maxillo-facial interventions of periosteal tibia grafts. 


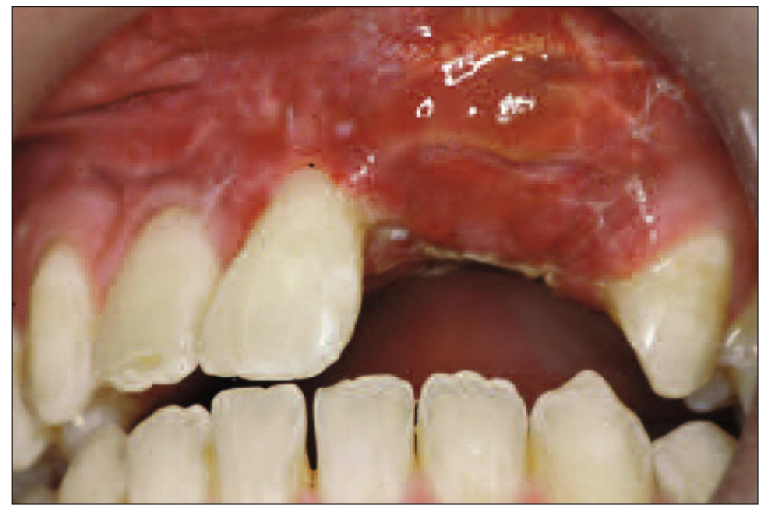

Figure 13

Result obtained immediately after periodontal plastic surgery with a thick graft of conjunctive tissue (15 days post-operatively-surgery performed by Dr. C. Molé).

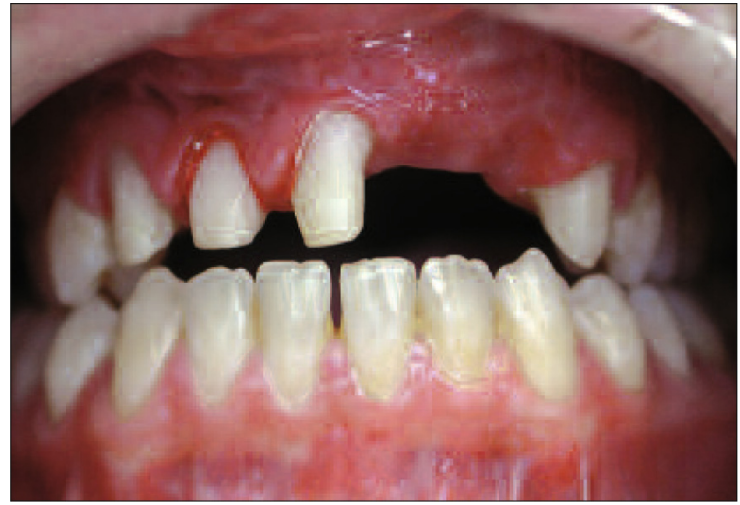

Figure 14

Four months after the surgery the volume of the crest is perfectly stable the practitioner can commence first steps in preparing a bridge that will serve as a retainer for the spaces assigned to replacement roles on the border of the cleft.

\section{Case $n^{\circ} 1$}

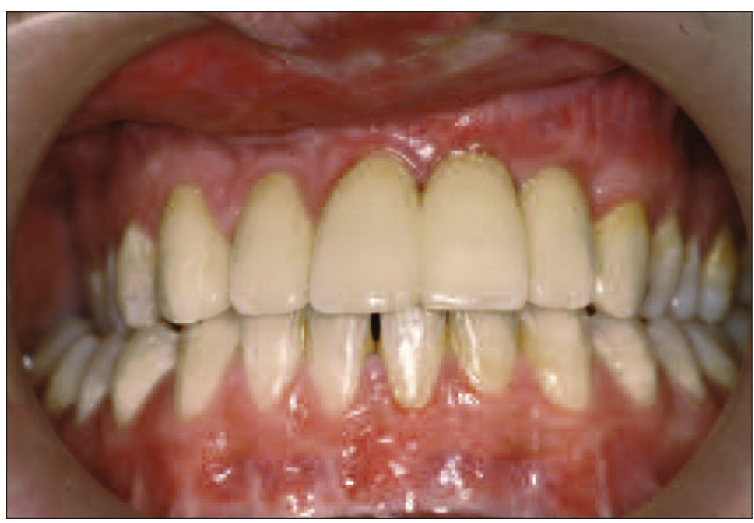

Figure 15

Fixed prosthetic reconstruction borne by upper right central and upper left canine to reestablish esthetics and function under conditions that will assure stability thanks to the well restructured periodontium and the well-stabilized Case $n^{\circ}$ 1occlusion (Dr. C. Billiotte constructed the prosthesis).

titioners face is to bring cleft patients to a situation equivalent to that presented by a patient who has simply lost a single tooth ${ }^{4}$.

Practitioners must not let the perspective of successful implant placement make them forget the supplementary surgical steps that it imposes, which demand patients un- dergo additional treatment and bear the cost of financing it.

\section{- Successful implant surgery}

Placement of implants is rarely possible at the start of cleft treatment.

According to Lalo et al., reporting on a small sample of 12 patients, after primary bone grafts, only $75 \%$ 


\begin{tabular}{|l|l|}
\hline \multicolumn{1}{|c|}{ Favorable criteria } & \multicolumn{1}{c|}{ Unfavorable criteria } \\
\hline Adult patient & Healthy dentition \\
\hline One or more congenitally absent teeth & Malpositioned tooth or teeth \\
\hline Malpositioned tooth or teeth & Mobility of osseous fragments \\
\hline Marked hypoplasia or dysplasia of teeth & $\begin{array}{l}\text { Significant discrepancy between positions of } \\
\text { upper and lower basal bone }\end{array}$ \\
\hline $\begin{array}{l}\text { Osseous or epithelio-conjunctive bridge } \\
\text { between borders of cleft (tibial, } \\
\text { gingivoperiostoplasty, deep conjunctive graft) }\end{array}$ & $\begin{array}{l}\text { Bucco-nasal communication, alveolar breach } \\
\text { and/or residual palatal division }\end{array}$ \\
\hline $\begin{array}{l}\text { Stable or unstable occlusion, as an effect } \\
\text { Retention }\end{array}$ & \\
\hline
\end{tabular}

Table /I

of patients were judged to be good candidates for implants and $50 \%$ of this group would need supplementary amounts of osseous support for implants to succeed. So $25 \%$ of this sample required three rather serious interventions to make their chosen sites suitable for implants.

We should remember that with patients who have no other arch problems, the success rate for implants in bone grafts ranges from 95.9 to $97.2 \%$.

Finally, these figures reflect only a small evocation of the achievement of the osteointegration needed for implants.

\section{- Prosthetic and esthetic success}

No studies evaluating the qualitative and the quantitative aspects of finished esthetics for cleft patients have as yet been published in the literature we reviewed. Many of the articles were deceiving with regard to the gravity of the therapeutic challenge.
Lalo et al. reported that they used implants to complete $75 \%$ of their cases, but they had to be supported by prosthetic rehabilitation with false gingiva, which, unfortunately, diminished the success of the final esthetic result.

Often, osseous deficit imposes a faulty implant placement that will leave the crowns they support leaning away from an upright position or tilt palatally lending an unpleasing appearance to their profile of emergence and making them imperfectly adapted to biomechanical needs. Even in cases where surgeons place secondary or even tertiary bone grafts we have been forced to observe that the results of reconstructions have been, over the long term, insufficiently consistent (cf. clinical case $n^{\circ} 2$, Figs. 22 and 23)

- Clinical case $\mathbf{n}^{\circ} \mathbf{2}$ (Figs. 16 to 223 ).

- Criteria for decision making (Table III) 


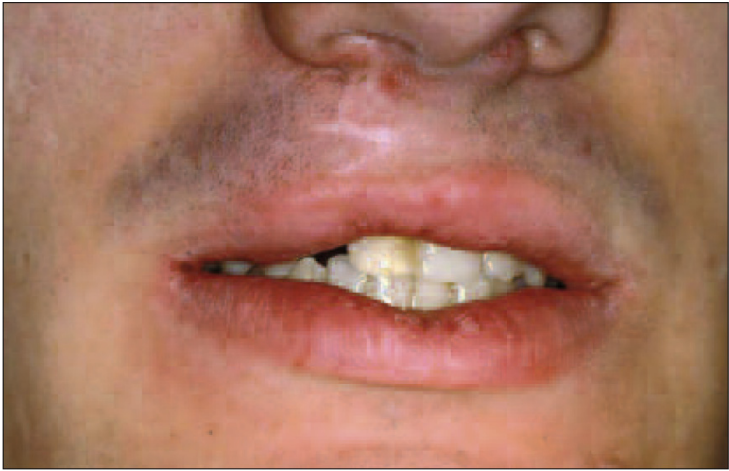

Figure 16

Sequelae of a right unilateral cleft. Although well repaired, the lip has insufficient support.

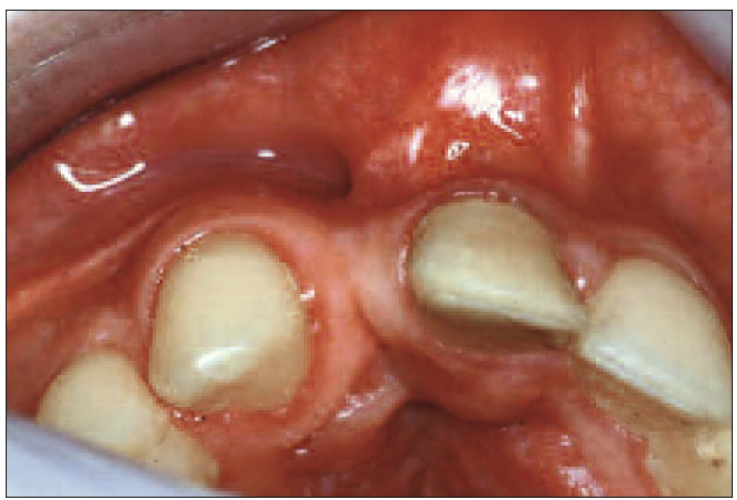

Figure 18

Despite initial surgery there is still a deficit of crestal bone.

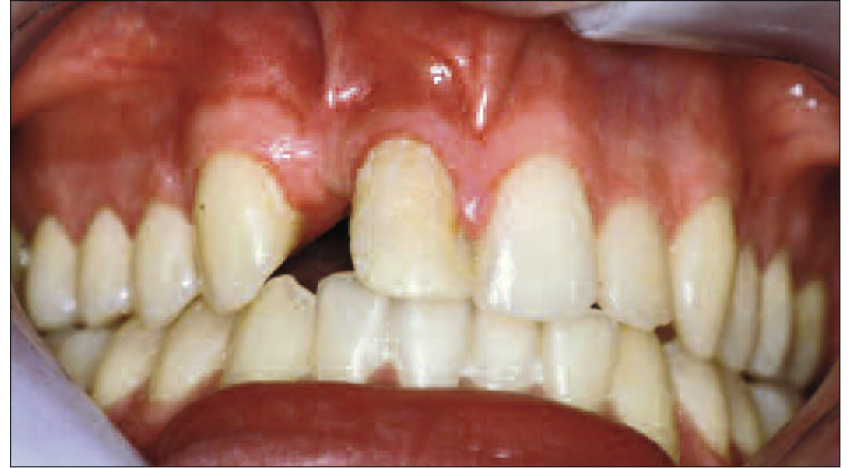

Figure 17

Agenesis of the right upper lateral incisor on the site of the cleft where a secondary bone graft had already been placed.

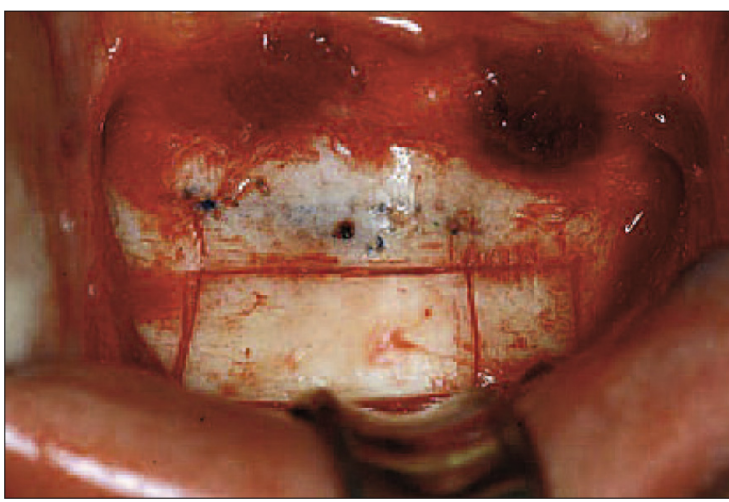

Case

$n^{\circ} 2$

Figure 19

Harvesting cortico-spongy bone from the chin area of the mandible with osteotomies performed by piezoelectric surgery.

storation. The one disadvantage is that the hooks by necessity are often visible.

\section{- Acrylic or metal removable pros- thesis?}

An acrylic removable prosthesis has the advantage of being the least expensive but it is not recommended when the periodontium is fragile ${ }^{30}$.

A cast metal prosthesis is much more expensive but more comfortable and obtains a better result. 


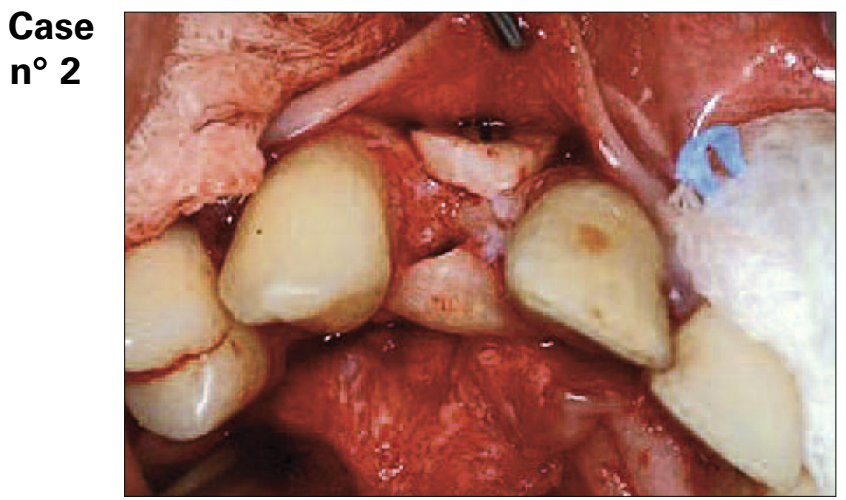

Figure 20

Double appositional bone graft, buccally and palatally with osteosynthesis with transfixing screws to establish I crestal curvature (surgery by Dr. C. Molé).

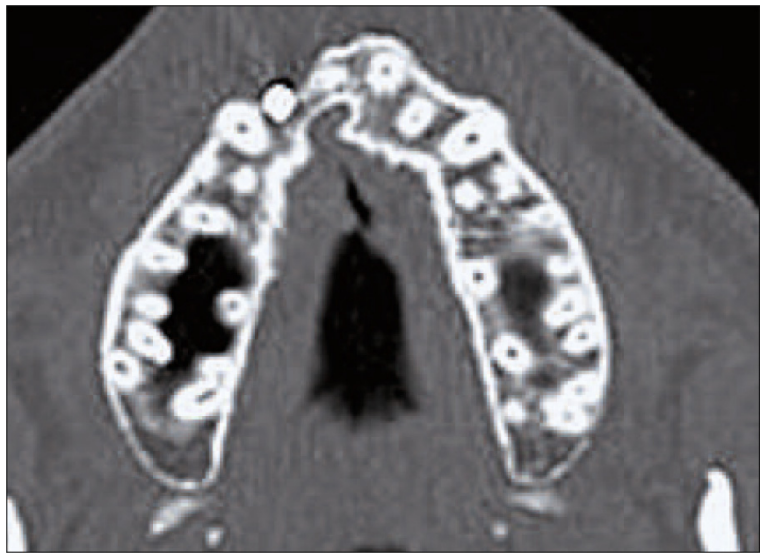

Figure 22

Three years after the implanto-prosthetic reconstruction, the patient consulted us for nasal surgery. We sent him for a scanner examination: it demonstrated the progressive resorption of the external cortical graft placed before implant insertion.

Because of its rigid base, it ensures excellent retention. However, the casting of the skeletal plate requires a normal hard palate.

\section{- Decisional criteria}

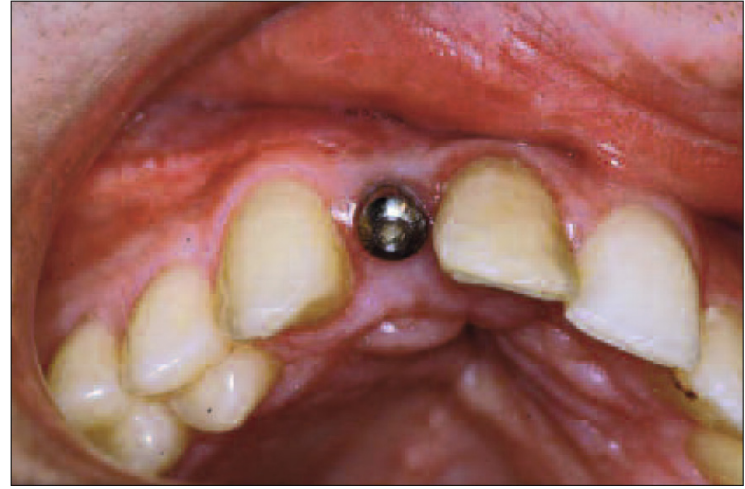

Figure 21

After reconstruction and alveolar healing, the practitioner was able to place the implant under apparently ideal conditions for its three dimensional situation.

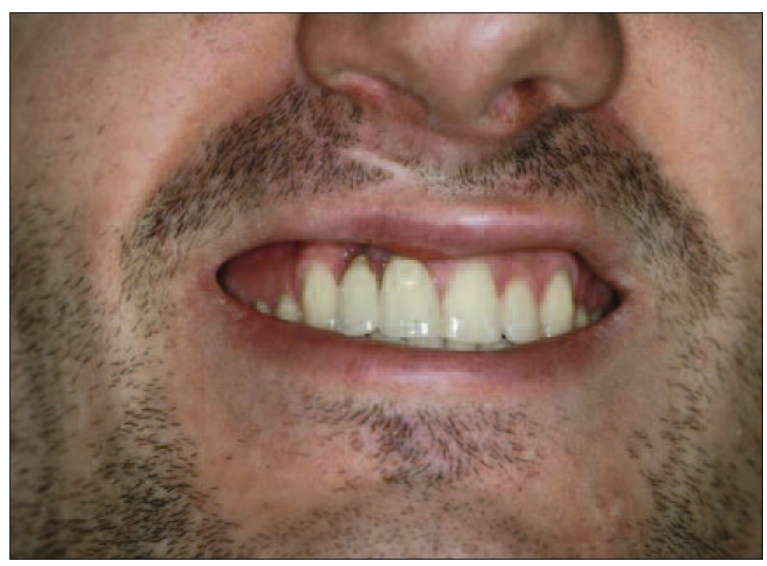

Figure 23

This clinical view shows the supporting tissue deficit around the implant, which is progressively worsening. We are considering a new connective tissue graft to remedy the situation.

\section{3 - 5 - The full removable denture}

Of course, a full denture is never a solution at the end of the growth period. However, a gross failure to manage the treatment of several patients 


\begin{tabular}{|c|c|}
\hline Favorable parameters & Unfavorable parameters \\
\hline Adult patient & General contraindications \\
\hline Agenesis & Weakened periodontium on border teeth \\
\hline $\begin{array}{l}\text { Early graft, interceptive surgery or at the time } \\
\text { of the implantation }{ }^{8,17}\end{array}$ & Fine biotype, absence of keratinized gingiva \\
\hline Conjunctival epithelial graft & Bergland index score 3 or 4 \\
\hline Bergland index score 1 and maybe $2^{5}$ & Dental malpositions \\
\hline Stable occlusion (no need for retention) & $\begin{array}{l}\text { Alveolar gap, residual palatal division and/or } \\
\text { buccal-nasal opening }\end{array}$ \\
\hline & Greater esthetic demands \\
\hline
\end{tabular}

Table III

\begin{tabular}{|c|c|}
\hline Favorable parameters & Unfavorable parameters \\
\hline Contraindication of implant surgery & Patient wants to wear a fixed prosthesis \\
\hline Contraindication of a fixed prosthesis & $\begin{array}{l}\text { For an acrylic removable prosthesis: period- } \\
\text { ontal disease }\end{array}$ \\
\hline $\begin{array}{l}\text { Provisional solution in case of one } \\
\text { missing tooth, after mucco-gingival }\end{array}$ & $\begin{array}{l}\text { For cast metal prosthesis: irregular hard } \\
\text { palate, fish mouth or bumpy palate }\end{array}$ \\
\hline $\begin{array}{l}\text { Stable or unstable occlusion (stabilizes the oc- } \\
\text { clusion) }\end{array}$ & Supernumerary flanges or frenums \\
\hline Healthy or cleaned dentition & Esthetics: hooks \\
\hline \multicolumn{2}{|l|}{ Alveolar-palatal obturator } \\
\hline Least expensive, fast & \\
\hline
\end{tabular}

Table IV

resulted in an edentulous upper jaw when they became young adults.

The different anatomical regions used when making a full removable denture in the maxilla are modified for a patient with a cleft. This modification complicates the installation process and the results in obtaining peripheral joint range of motion, which is the only way to guarantee acceptable prosthetic stability.

The role of the prosthesis is to compensate for the loss of alveolar ridge bone and tissue for esthetic 
and functional reasons. The dentist must adapt the prosthesis to the mucous flanges as well as sequelae of the cleft, and must not injure this sensitive region ${ }^{12}$.

The practitioner must adapt the impression phases to the possibility that oronasal fistulas are present ${ }^{11}$. The difficulty of class III skeletal malocclusion, typically linked to the evolution of growth in cases involving clefts, often entails an occlusion of convenience or end to end relation occlusion.

\section{3 - 5 - 1 - The supra-radicular removable prosthesis}

\section{- Indications}

The supra-radicular removable prosthesis is indicated when residual mobility of skeletal fragments, differences between root canal and crown, malpositions and tooth breakage are present $^{13,32}$ (Figs. 24 and 25).

This prosthesis can support the velo-palatal prosthesis ${ }^{19}$.

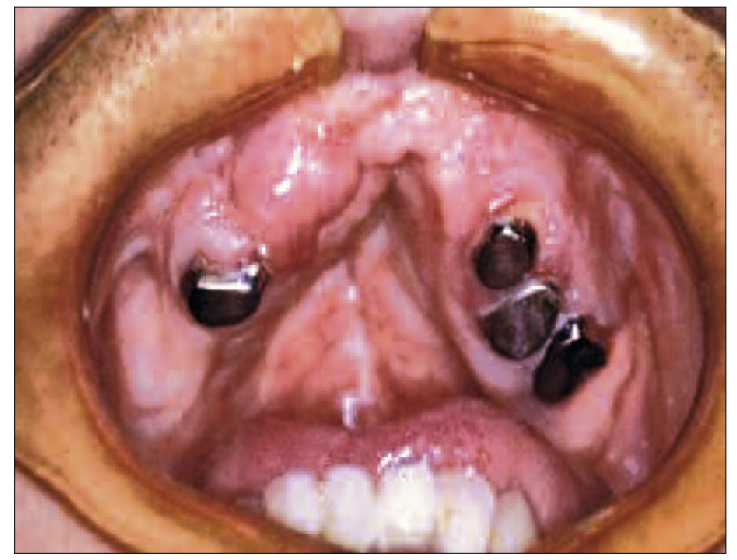

Figure 24

Partial edentulism of a patient presenting sequelae of a bilateral cleft. Some roots have been saved for implantation of magnetic anchors.
The disadvantages of this type of rehabilitation are numerous:

- dental undercuts are an unfavorable parameter,

- transfer of caries bacteria to confined zones,

- cost of bar gold copings and attachments,

- corrosion of the magnet sensor elements,

- residual mobility.

\section{3-5 - 2 - The removable implant retained prosthesis}

\section{- Indications}

The removable implant retained prosthesis is indicated in cases involving sequelae that affect the osseous bases causing patients to become completely edentulous with a hypotrophic or even totally destroyed maxillary ${ }^{30}$.

This prosthesis facilitates the management of Ballard class III skeletal discrepancies often encountered in patients with a cleft.

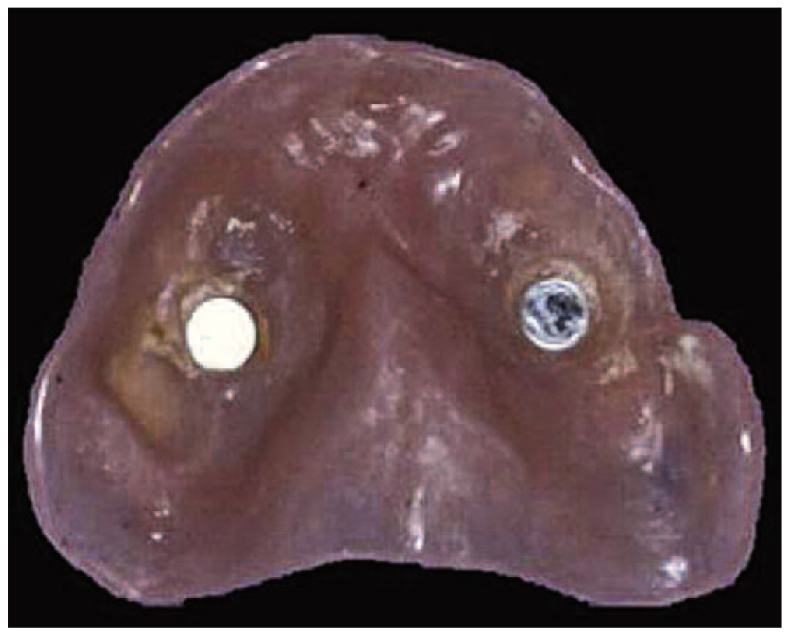

Figure 25

Removable complete denture with retention screws and magnetic stabilizers. 


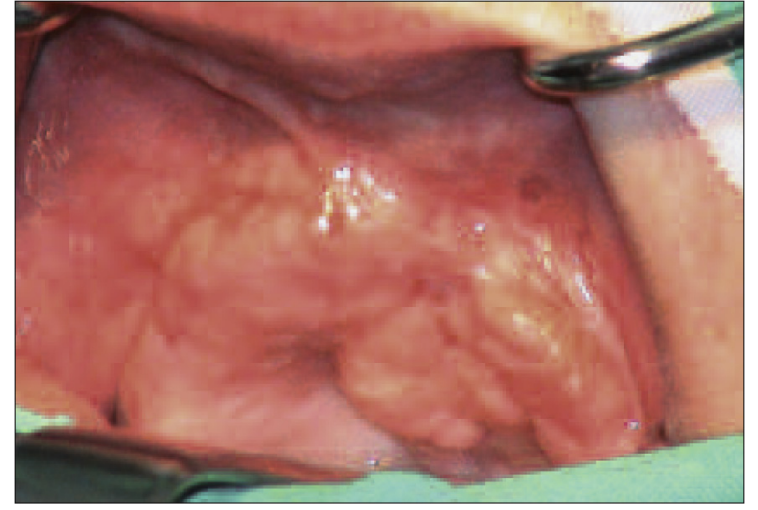

Figure 26

Completely edentulous maxilla with a sequela of a left unilateral cleft. The dysmorphic appearance of the crestal bone considerably limits how well the full denture can perform.

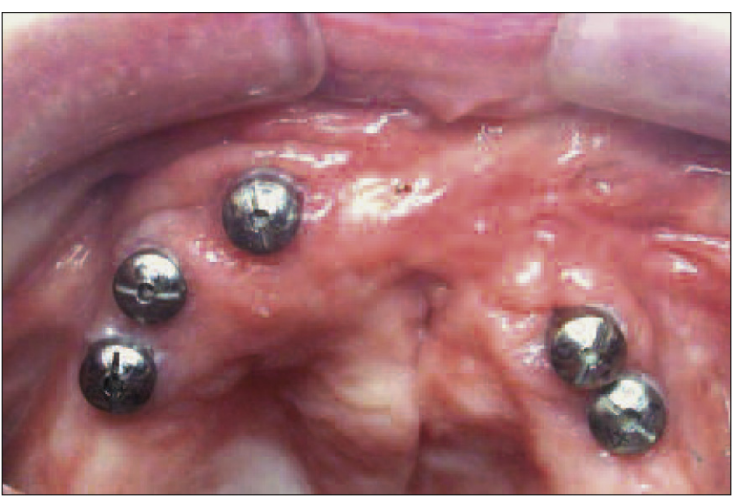

Figure 28

Trans-muccosal actuation of implants after healing by osseointegration.

Lastly, the removable implant retained prosthesis is a solution to keep in mind for all cases where the residual mobility of a removable prosthesis is unacceptable.

Osseointegration of dental implants is a valuable alternative for obtaining an increased mechanical retention, a strong support base, and an effective stabilization of the remo-

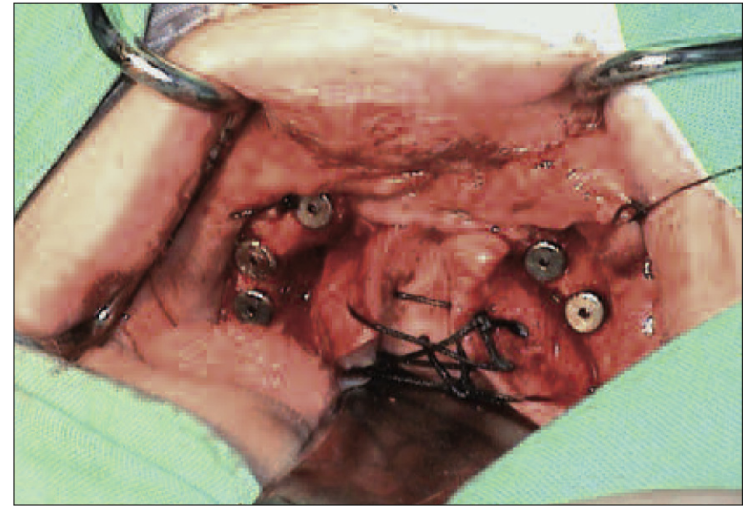

Figure 27

The placement of five dental implants is initiated to make it possible to install fixed prosthetic anchors (surgery: Dr. C. Molé).

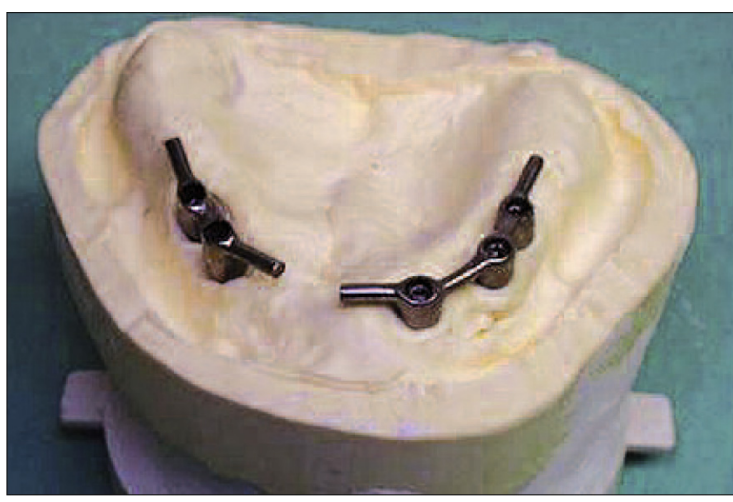

Case

$n^{\circ} 3$

Figure 29

The casts for cast bar fabrication of two anchors.

vable prosthesis that at times supports an obturator ${ }^{1,16,26}$ (cf. clinical case $n^{\circ} 3$ Figs. 26-31).

- Clinical case $\mathbf{n}^{\circ} \mathbf{3}$ (Figs. 26 to 33 )

Ideally, the dentist should be able to minimally install two small fragment implants. The research data show that a continuous bar retainer can be used to connect the pillars and strengthen the two small 


\section{Case $n^{\circ} 3$}

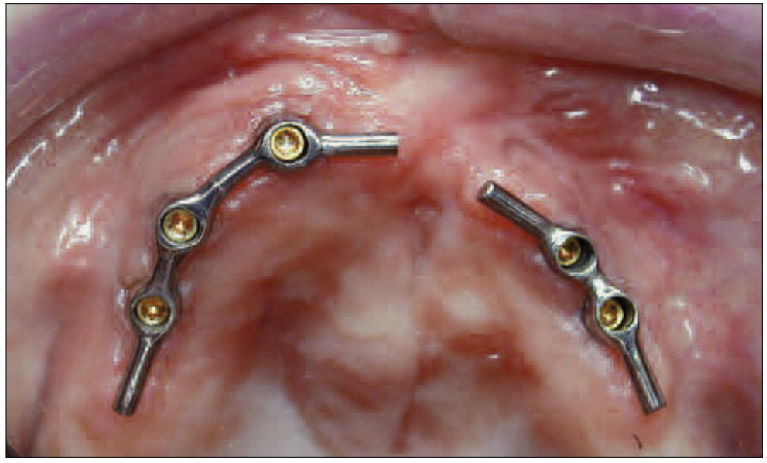

Figure 30

Installation of two anchor abutments on five osseointegrated implants. Occlusal view (prosthesis: Dr. N. Château).

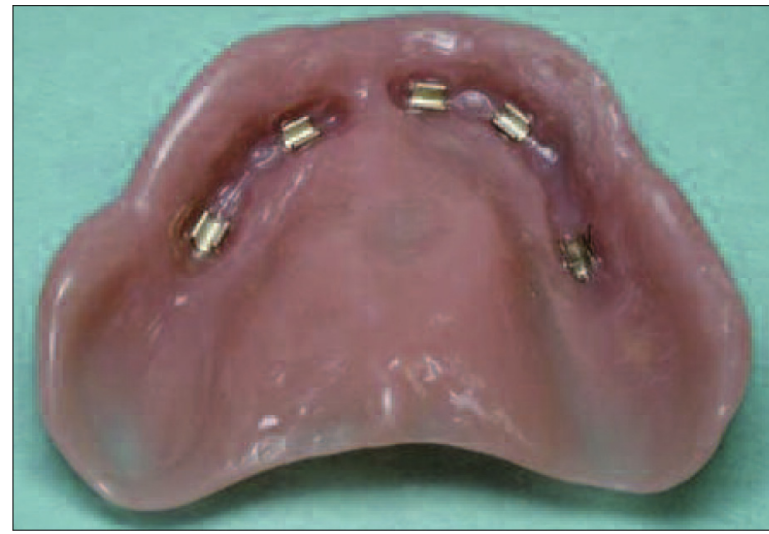

Figure 32

Full removable denture providing retention and stability with platform switching for implant bars.

fragment implants in cases of unilateral LMPC.

Two separate bar retainers are sometimes preferable since it is difficult to achieve passivity and not exert pressure on the anchor. The implants are buried for approximately 5 to 6 months and afterward the

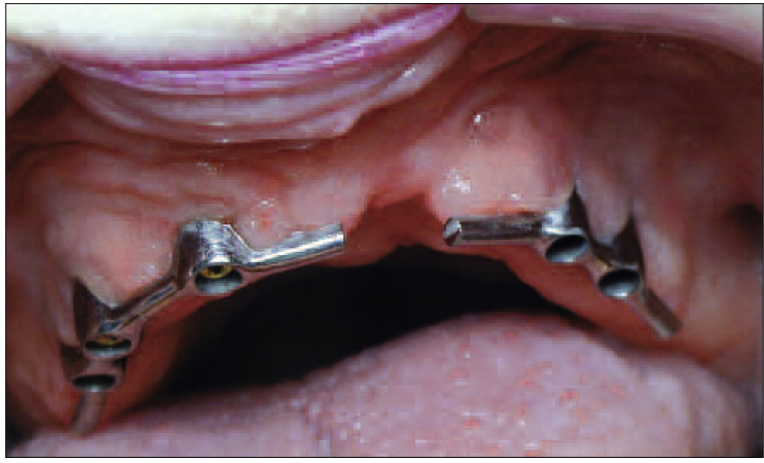

\section{Figure 31}

Idem on buccal view. Note the very reduced crowding on crestal bone.

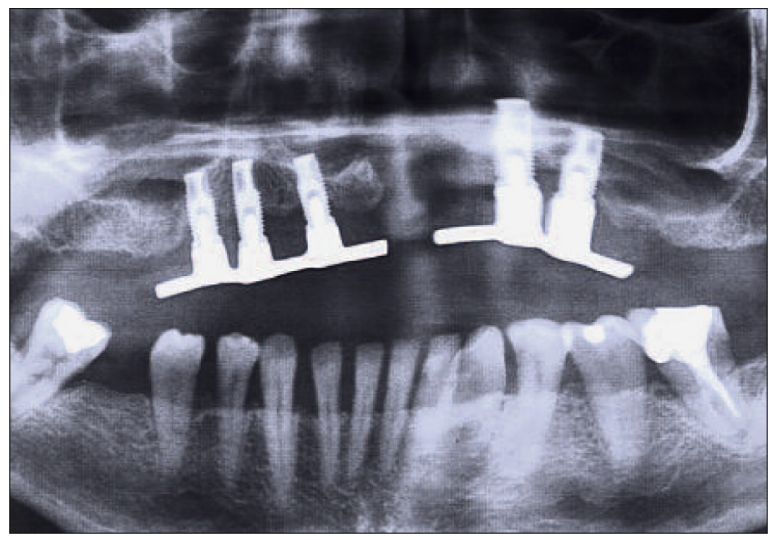

Figure 33

Surgical prosthetic stability post operative assessment after 3 years (occlusal view) in contact with opposing dentulous arch.

prosthetic stages are the same as those used for a patient who does not have a cleft.

According to Williams, the combination of ERA bar plus 4 clips Hader design was the most retentive attachment ${ }^{40}$.

- Decisional criteria (Table V) 


\begin{tabular}{|c|c|}
\hline Favorable parameters & Unfavorable parameters \\
\hline Completely edentulous patient & Contraindication of bone/implant surgery \\
\hline Alveolar sequelae & Insufficient osseous quantity/quality \\
\hline Atrophy of the premaxilla bones & Financial cost \\
\hline Significant discrepancy of bone bases & \\
\hline
\end{tabular}

Table $\mathrm{V}$

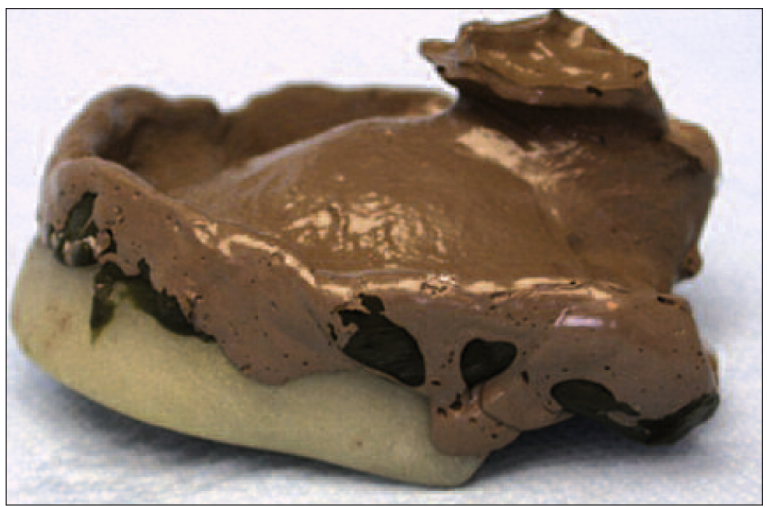

Figure 34

Tertiary mold made with polysulfurs after peripheral remargining with Kerr's paste.

\section{3 - 5- 3 - Alveolar-palatal prosthesis}

In the case of an alveolar-palatal prosthesis, the obturator part is made after the plate.

\section{- Indications}

The indications for alveolar-palatal prostheses are relatively limited

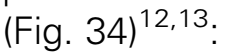

\section{4 - CONCLUSION}

Two main ideas, that are more or less opposed to one another, describe the prosthetic rehabilitation of a patient with a LMPC:

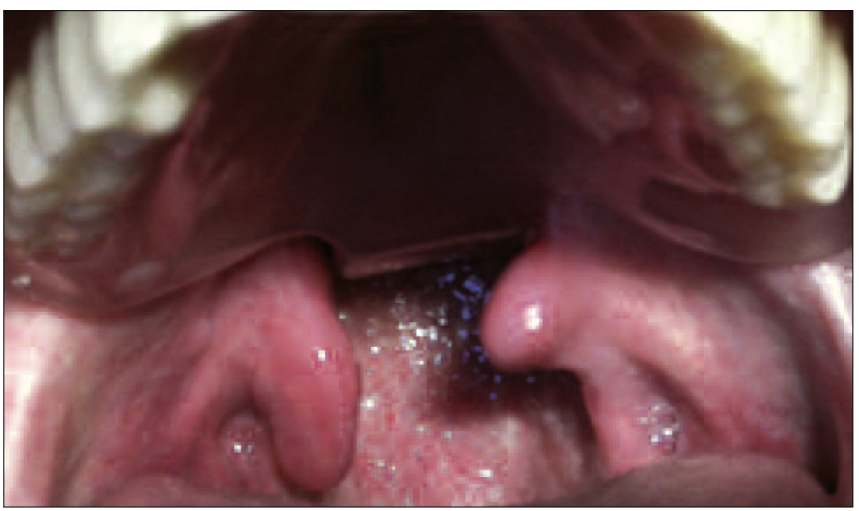

Figure 35

Supplemental retention and obturation for the velar extension created by the palatal prosthesis.

- contra-indications to surgery or general anesthesia,

- refusal of the patient to undergo surgery,

- previous surgical failures impossible to resume,

- surgical insufficiency.

- the idea that it is difficult to generalize and to create a standard protocol in this type of rehabilitation, since the sequelae and the clinical 
shapes of clefts are too numerous and varied;

- the idea that a prosthesis, in technical terms, has no particular specificity and that all the classic possibilities, can be considered. However, the oral-facial region particular to LMPC indicates numerous constraints that can add up to often make rehabilitation very complicated.

The choice and the fabrication of a prosthesis must be adapted to the sequelae, to functional problems and to end result esthetic demands. These two factors depend on the alveolar-dental management of the patient in advance. The strategy leading up to the surgical prosthesis must adhere to a multi-factorial analytical approach and must be integrated into a harmonious interdisciplinary therapy.

Managing the prosthetic rehabilitation of a patient presenting sequelae of LMPC requires the practitioner to implement an array of skills that include a solid understanding of both the specific pathology and the therapeutic history specific to each case. The dentist must therefore intervene comprehensively by implementing a strategic team approach, with the orthodontist and other medical staff.

\section{Acknowledgements}

The authors wish to particularly thank:

- Professor Michel STRICKER for the quality of his scholarly contributions and for his influence on the development of clinical research for the treatment of LMPC;

- Dr. Christophe BILLIOTTE for his active participation in the prosthetic rehabilitation of patients from the Maxillo-facial surgery Center, who presented sequelae of LMPC.

\section{REFERENCES}

1. Abreu A, Levy D, Rodriguez E, Rivera I. Oral rehabilitation of a patient with complete unilateral cleft lip and palate using an implant-retained speech-aid prosthesis: clinical report. Cleft Palate Craniofacial J 2007;44(6):673-7.

2. Aknin JJ. Le point sur les fentes labioalvéolopalatines. Rev Orthop Dento Faciale 2008:42;391-402.

3. Benoit R, Leduc JP, Genon P. Considérations orthodontiques et parodontales pour la mise en place des canines en bordures des fentes labio-alvéolaires. J Parodontologie 1989;8:13954.

4. Bichet $A$. Place du chirurgien-dentiste et de la réhabilitation prothétique dans la prise en charge interdisciplinaire des séquelles de fentes. Thèse Chir Dent. Nancy: Univ., 2011.

5. Boland FX, Drikers S, Persac S, Peron JM, Delcampe P. Gingivopériostoplasties associées à une greffe osseuse : évaluation radiologique. Rev Stomatol Chir Maxillofac 2009;110:193-7.

6. Bonin B, Picard A, Stricker M. L'évolution du maxillaire chez les sujets porteurs de fente unilatérale totale opérés par la technique de la greffe périostée : étude rétrospective de 15 cas opérés avec 18 ans de recul. Rev Stomatol Chir Maxillofac 2001;102(3-4):162-8.

7. Borghetti A, MonnetCorti V. Chirurgie plastique parodontale. Paris : CdP, Collection JPIO, 2008. 
8. Captier G, Bigorre M, Mattei L, Delestan C, Montoya P. La greffe osseuse secondaire dans les fentes labio-maxillo-palatines totales: modalités techniques et indications à propos de 62 greffes. Ann Chir Plas Esthét 2003;48:20-30.

9. Chancholle AR, Saboye J, Tournier JJ. Prise en charge des fentes labio-palatine pour I'équipe du Docteur Chancholle à Toulouse. Ann Chir Plast Esthét 2002;47:92-105.

10. Cortés J, Granic X. Caractéristiques cranio-faciales chez un groupe de patients chiliens atteints de fente labio-maxillo-palatine unilatérale opérée. Rev Stomatol Chir Maxillofac 2006;107:34753.

11. Destruhaut F, Fusaro $S$, Vigarios E, Pomar P. Prothèse maxillo-faciale et syndrome EEC. Stratégie prothétique 2008;8(2):14350.

12. Destruhaut F, Vigarios E, Pomar P. Divisions vélo-palatines non opérées approche fondamentale et thérapeutique en prothèse maxillo-faciale. Médecine Buccale, 2011; [28-560-P10].

13. Dichamp J, Leydier MC, Leydier J, Guilbert F, Roisin LC. Prothèse vélo-palatine. Encycl Méd Chir (Elsevier SAS, Paris) Stomatologie 1993;[22-066-B-50].

14. Duret $A$, Delcampe $P$, Peron JM. Les séquelles maxillaires dans les fentes labioalvéolopalato-vélaires. Prise en charge orthodontique. Rev Stomatol Chir Maxillofac 2007; 108:301-5.

15. Genon P. Comblement chirurgical des fentes alvéolaires par autogreffe conjonctive. J Parodontologie 1991;10(3/91):297-303.

16. Harrison JW. Dental implants to rehabilitate a patient with an unrepaired complete cleft of the hard and soft palate: a clinical report. Cleft Palate J 1992;29:485-8.

17. Lalo J, Kayali A, Toudjine B, Majourau-Bouriez A, Essaddam H, Pavy B. Réhabilitation implantaire des fentes labio-palatines : étude rétrospective sur dix ans. Rev Stomatol Chir Maxillofac 2007;108:398-406.

18. Lesne C. L'orthodontiste et l'enfant porteur de fente. Orthod Fr 2004;75:253-6.

19. Leydier J. Obturateurs vélo-palatins. Actual Odonto Stomatol 1988;162;397-405.

20. Martinez H, Renault P, Georges-Renault G, Pierrisnard L, Rouach T. Les implants : chirurgie et prothèse. Choix thérapeutique stratégique. Paris : CdP, Coll. JPIO, 2008.

21. Mercier J. La gingivoplastie dans les fentes labio-maxillaires. Rev Stomatol Chir Maxillofac 2001; 102(3-4):206-10.

22. Molé C, Simon E, Billiotte C, Stricker M. Choix chirurgico-prothétiques dans la gestion alvéolaire des séquelles de fentes labio-maxillo-palatines. Orthod Fr 2010;81:11326.

23. Molé $C$, Stricker M. Réhabilitation postorthodontique des séquelles de fente alvéolaire : implantation ou chirurgie plastique parodontale. Orthod Fr 2004;75:339-48.

24. Morand B, Lebeau J, Raphël B. Les séquelles nasales dans les fentes bilatérales. Rev Stomatol Chir Maxillofac 2007;108:289-96.

25. Morand B, Duroure F, Raphaël B. Le déficit osseux des fentes labio-maxillo-palatines : revue des procédés. Expérience de la greffe périostée tibiale. Orthod $\mathrm{Fr}$ 2004;75:217-28.

26. Pham AV, Abarca M, De Mey A, Malevez C. Rehabilitation of a patient with cleft lip and palate with an extremely edentulous atrophied posterior maxilla using zygomatic implants: case report. Cleft Palate Craniofac J 2004;41:571-4.

27. Picard A, Diner PA, Labbé D, Nicolas J, Tomat C, Seigneuric JB, Vazquez, Bénateau $\mathrm{H}$. Les séquelles maxillaires dans les fentes labio-alvéolo-palato-vélaires. Place de la distraction ostéogénique. Rev Stomatol Chir Maxillofac 2007;108:313-20.

28. Quirynen M, Naert I, Van SteenBerghe D, Teerlinck J, Dekeyser C, Theuniers G. Periodontal aspects of osseointegrated fixtures supporting overdenture. A 4-year retrospective study. J Clin Periodontol 1991;18:719-28.

29. Raoul G, Ferri J. Les fistules palatines résiduelles dans les séquelles de fentes labioalvéolopalatovélaires. Rev Stomatol Chir Maxillofac 2007;108:321-8.

30. Raoul G, Ferri J. Particularités de la réhabilitation dentaire prothétique dans les séquelles de fentes. Rev Stomatol Chir Maxillofac 2007;108:378-82. 
31. Reiseberg DJ. Dental and prosthodontic care for patients with cleft or craniofacial conditions. Cleft Palate Craniofacl J 2000;37(6):534-7.

32. Roisin LC, Dichamp J, Dubruille JH. Traitement prothétique terminal des fentes faciales (classification et intérêt des techniques mobiles et fixées). Actual Odonto Stomatol 1988;162:379-88.

33. RomagnaGenon C, Genon P. Esthétique et parodontie : les clés du succès. Paris : CdP, Coll. JPIO, 2001.

34. Salvi GE, Bräger U, Lang NP. Periodontal attachement loss over 14 years in cleft lip, alveolus and palate (CLAP, CL, CP) subjects not enrolled in a supportive periodontal therapy program. J Cin Periodontal 2003;30:840-5.

35. Simon E, Duroure F, Coing C, Sellal S, Chassagne JF, Stricker M. Principes de prise en charge des fentes labio-maxillo-palatines unilatérales totales : Proposition de protocole. Orthod Fr 2004;75:229-41.

36. Simon E, Weissenbach O, Mole C, Stricker M. Prise en charge des fentes labiomaxillo-palatines : protocole de Nancy. Rev Orthop Dento Faciale 2011;45:301-9.

37. Stricker M. Le vestibule buccal supérieur dans les fentes. Rev Stomatol Chir Maxillofac 1987;88: 116-9.

38. Talmant JC, Talmant JCh, Lumineau JP. Les séquelles nasales des fentes unilatérales : analyse et prise en charge. Rev Stomatol Chir Maxillofac 2007;108:275-88.

39. Vanwijck R, Bayet $B$, Roffé JL, Compère JF, Benateau H. Les séquelles labiales dans les fentes uniet bilatérales. Rev Stomatol Chir Maxillofac 2007;108:265-74.

40. Williams BH, Ochiai KT, Hojo S, Nishimura R, Caputo AA. Retention of maxillary implant overdenture bars of different designs. J Prosthet Dent 2001;86:603-7. 